\title{
Pengembangan Kurikulum Pendidikan Moral Agama pada Pendidikan Taman Kanak-Kanak
}

\author{
Tarsono, Agus Salim Mansyur, Uus Ruswandi \\ Pascasarjana Pendidikan Agama Islam, Universitas Islam Negeri Sunan Gunung Djati Bandung, Indonesia \\ e-mail: tarsono@uinsgd.ac.id
}

\begin{abstract}
This study aims to identify, analyze, and develop a curriculum of religious moral education in kindergartens. The method used in this research is the $R \& D$ method (research and development) with the technique of taking data from the study of documentation, observation, questionnaires, and interviews. The results showed that: 1) the developed religious moral education curriculum was more focused on habituating positive behavior, instilling independence and discipline, and fostering faith and loyalty. These three developments applied to routine activities at school; 2) the implementation of curriculum development in religious moral education carried out in three stages, namely the preparation, development, and reporting stages; 3) the development of religious moral education curriculum has advantages, namely: the existence of a curriculum that leads to character education and self-development, the number of religious activities, professional educators, moral and religious education materials integrated with other aspects, facilities, and infrastructure that are complete and neatly arranged.
\end{abstract}

Keywords: curriculum development, religious moral education, kindergarten

\begin{abstract}
Abstrak
Penelitian ini bertujuan untuk mengidentifikasi, menganalisis dan mengembangkan kurikulum pendidikan moral agama pada Taman Kanak-Kanak. Metode yang digunakan dalam penelitian ini yaitu metode research \& development dengan teknik pengambilan data dokumentasi, observasi, angket, dan wawancara. Hasil penelitian menunjukkan bahwa: pertama, kurikulum pendidikan moral agama yang dikembangkan lebih difokuskan pada pembiasaan perilaku positif, penanaman kemandirian dan disiplin, serta pembinaan keimanan dan ketakwaan. Kegiatan-kegiatan pengembangan tersebut diterapkan pada kegiatan rutin di sekolah; kedua, implementasi pengembangan kurikulum pendidikan moral agama dilakukan dengan tiga tahap yaitu tahap persiapan, pengembangan dan pembuatan laporan; ketiga, pengembangan kurikulum pendidikan moral agama memiliki keunggulan yaitu: adanya kurikulum yang mengarah pada pendidikan karakter dan pengembangan diri, banyaknya kegiatan keagamaan, pendidik yang profesional, materi pendidikan moral dan agama yang diintegrasikan dengan aspek lainnya, sarana dan prasarana yang lengkap dan tersusun rapi.
\end{abstract}

Kata Kunci: pengembangan kurikulum, pendidikan moral agama, taman kanak-kanak

\section{Pendahuluan}

Pendidikan anak usia dini adalah pendidikan terpenting karena usia dini merupakan masa unik dalam kehidupan anak-anak. Usia ini merupakan masa pertumbuhan yang paling peka dan sekaligus paling sibuk. Pentingnya pendidikan anak usia dini menuntut pengajar untuk melaksanakan kegiatan pembelajaran yang memusatkan perhatian pada anak. Sebab anak merupakan dambaan bagi setiap orang tua dan generasi penerus bangsa, namun salah satu permasalahan yang muncul adalah tidak setiap orang tua atau pendidik memahami cara yang tepat dalam mendidik anak usia dini. Dengan demikian, tidak sedikit orang tua mengalami kekecewaan, karena anak sebagai tumpuan harapan ternyata tidak sesuai yang diharapkan (Wahyuningsih \& Suyanto, 2015).

Anak merupakan investasi yang sangat penting bagi penyiapan sumber daya 
manusia (SDM) di masa depan (Prakoso dkk., 2020). Dalam rangka mempersiapkan SDM berkualitas untuk masa depan, pendidikan merupakan salah satu hal yang penting untuk diberikan sejak usia dini, di samping juga anak harus dipenuhi kebutuhan lainnya, misalnya kebutuhan akan gizi (Cahyaningrum dkk., 2017). Usia dini merupakan masa penting, karena dalam masa ini ada era yang dikenal dengan masa keemasan (golden age). Masa keemasan hanya terjadi satu kali dalam perkembangan kehidupan manusia. Pada masa ini merupakan masa kritis bagi perkembangan anak. Jika dalam masa ini anak kurang mendapat perhatian dalam hal pendidikan, perawatan, pengasuhan dan layanan kesehatan serta kebutuhan gizinya, maka dikhawatirkan anak tidak dapat tumbuh dan berkembang secara optimal (Rustini, 2018). Dalam pendidikan anak usia dini salah satu kawasan yang harus dikembangkan adalah moral agama, karena dengan diberikannya pendidikan moral agama sejak usia dini, diharapkan pada tahap perkembangan selanjutnya anak akan mampu membedakan baik buruk, benar salah, sehingga ia dapat menerapkannya dalam kehidupan sehari-hari (Fadlyana \& Larasaty, 2016).

Pendidikan adalah proses pembimbingan dan bimbingan secara sadar oleh pendidik terhadap perkembangan jasmani dan rohani anak didik menuju terbentuknya kepribadian yang utama. Marimba (dalam Tafsir, 2007) mencoba mendefinisikan pendidikan secara luas yakni usaha meningkatkan diri dalam segala aspeknya (Tafsir, 2007). Pendapat Tafsir tampaknya lebih melihat bahwa manusia sebetulnya memiliki kemampuan untuk dapat mendewasakan dirinya sendiri di samping melalui bimbingan orang lain untuk mencapai tujuan hidup yang diharapkan.

Terdapat dua ahli yang menjelaskan bagaimana perkembangan moral pada anak, yaitu Jean Piaget dan Kohlberg. Piaget (Hurlock, 2014) membagi perkembangan moral pada anak menjadi dua tahap, yaitu tahap realisme moral atau moralitas oleh pembatasan dan tahap moralitas autonomi atau moralitas oleh kerjasama atau hubungan timbal balik. Pada tahap pertama perilaku anak dikendalikan oleh ketaatan secara otomatis terhadap peraturan. Anak belum dapat melakukan penalaran atau penilaian terhadap aturan atau norma yang dikenakan padanya, sehingga anak masih memandang kaku pada aturan-aturan tersebut. Pada tahap ini anak memandang benar atau salah atas dasar konsekuensinya dan bukan berdasarkan motivasi di balik itu. Tahap ini terjadi pada anak usia 2 hingga 7 tahun. Pada usia 7 sampai 12 tahun anak memasuki tahap perkembangan moral autonomi. Pada tahap ini anak tidak kaku lagi dalam memandang aturan. Konsep anak dalam memandang aturan secara bertahap berubah dan dimodifikasi. Apabila anak usia lima tahun memandang berbohong selalu salah, maka pada anak usia di atasnya memandang berbohong tidak selamanya salah, kadang-kadang dibenarkan selama ada alasan yang dapat diterima. Tahap kedua usia 7 sampai 12 tahun ini bersamaan dengan tahap perkembangan kognitif operasional formal, yaitu tahap dimana anak mampu untuk berfikir abstrak, memahami, dan memecahkan masalah berdasarkan asumsi, dalil atau teori tertentu. Berdasarkan karakteristik tahap perkembangan moral tersebut di atas, perkembangan moral anak usia dini termasuk dalam tahap perkembangan realisme moral dengan berbagai karakteristik seperti tersebut di atas (Suryana, 2016).

Kohlberg melanjutkan teori Piaget (dalam Danoebroto, 2015) dengan menguraikan perkembangan moral menjadi tiga tahap, yang masing-masing tahap dikelompokkan dalam dua stadium. Pada anak usia dini, perkembangan moral anak termasuk pada tahap perkembangan moral yang pertama, yaitu moralitas prakonvensional (Annisa, 2016). Tahap ini terjadi pada anak sekitar usia 4 hingga 9 tahun. Karakteristik khas pada tahap ini 
tingkah laku anak tunduk pada peraturan dari luar. Pada stadium pertama tahap ini perilaku anak dikendalikan oleh akibat fisik yang ditimbulkan dari perbuatannya yang biasanya muncul dalam bentuk hadiah dan hukuman. Misalnya anak tidak memukul adiknya ketika marah disebabkan takut apabila dimarahi atau dihukum orang tuanya. Pada stadium kedua anak berperilaku moral untuk mendapatkan penghargaan, misalnya anak senang membantu orang tua karena ingin mendapatkan hadiah, pujian ataupun perlakuan baik yang diberikan orang tua atau orang dewasa lain di sekitarnya (Wulandari dkk., 2017).

Setelah tahap pertama dilalui, perilaku anak akan meningkat pada tahap kedua yaitu tahap konvensional. Pada tahap kedua ini perilaku moral anak dikendalikan untuk menyesuaikan diri dengan peraturan yang sudah ditetapkan atau disepakati. Misalnya anak melakukan sesuatu karena ingin diterima atau ingin sama dengan kelompok teman sebaya. Pada tahap ketiga disebut juga tahap pascakonvensional. Pada tahap terakhir ini perilaku anak sudah dikendalikan oleh nilai atau prinsip-prinsip yang dipegangnya, sehingga memungkinkan memegang nilai-nilai atau aturan secara luwes (Khaironi, 2018).

Usia TK adalah saat yang paling baik bagi guru, untuk meletakkan dasar-dasar pendidikan nilai, moral dan agama kepada peserta didik. Walaupun peran orang tua sangatlah besar dalam membangun dasar moral dan agama bagi anak-anaknya, peran guru sekolah Taman Kanak-Kanak (TK) juga tidaklah kecil dalam meletakkan dasar moral dan agama bagi seorang peserta didik, karena biasanya anak-anak TK senang menuruti perintah gurunya (Holis, 2016).

Oleh karena itu, seorang guru TK harus selalu berupaya dengan berbagai cara agar dapat membimbing anak didiknya sehingga mempunyai kepribadian yang baik, yang dilandasi dengan nilai moral dan agama. Dengan diberikannya landasan pendidikan moral dan agama kepada anak TK, anak dapat belajar membedakan perilaku yang benar dan salah. Contohnya, di TK seorang anak didik dapat belajar bahwa mereka tidak boleh berbohong, mengambil barang yang bukan miliknya atau mengganggu orang lain (Irma dkk., 2019).

Pendidikan moral agama perlu dibangun dalam kehidupan anak sejak dini. Sebab untuk membangun masa depan dunia mesti dibangun dengan moral yang baik, dan moral tersebut harus dibangun dalam kehidupan anak sejak dini. Pembangunan ini dilakukan di rumah tangga sebagai lembaga pertama anak manusia dan juga dapat diajarkan melalui lembaga-lembaga khusus salah satunya adalah TK (Inawati, 2017). Akan tetapi dalam pembangunan pendidikan moral kepada anak usia dini melalui sebuah lembaga TK harus dengan menggunakan kurikulum yang benar-benar sesuai dengan levelnya. Di samping itu dengan adanya kurikulum akan terlaksana pendidikan moral yang sistematis serta dapat diukur tingkat keberhasilannya baik secara kuantitatif maupun kualitatif (Taubah, 2015).

Perkembangan moral agama pada anak usia dini merupakan tingkatan paling dasar yang dinamakan dengan penalaran moral prakonvensional dimana pada tahap ini anak belum menunjukkan internalisasi nilai-nilai moral secara kokoh. Namun sebagian anak usia dini ada yang sudah memiliki kepekaan atau sensitivitas yang tinggi dalam merespon lingkungannya baik itu positif maupun negatif. Misalkan ketika guru/ orang tua membiasakan anakanaknya untuk berperilaku sopan seperti mencium tangan orang tua ketika akan berangkat atau pulang sekolah, atau mengucapkan salam dan contoh-contoh positif lainnya maka dengan sendirinya perilaku seperti itu akan terinternalisasi dalam diri anak sehingga menjadi suatu kebiasaan mereka sehari-hari. Demikian pula sebaliknya kalau kebiasaan negatif dibiasakan kepada anak maka perilaku 
negatif itu akan terinternalisasi pula dalam dirinya (Jannah, 2015).

Berdasarkan studi pendahuluan di TK Islam Terpadu (IT) Salman Al-Farisi Bandung dan TK IT Al-Multazam Kuningan, yang merupakan lembaga pendidikan Taman Kanak-Kanak yang terkenal dalam bidang pembiasaan, dan banyak diminati oleh masyarakat karena berbagai macam materi pendidikan di dalamnya. Pendidikan moral agama adalah salah satu pendidikan yang ditawarkan oleh lembaga tersebut dalam visi dan misinya. Inilah yang membuat tertarik masyarakat untuk mendaftarkan anaknya ke sekolah tersebut, karena para orang tua menganggap sekolah ini memiliki pengaruh dalam mengembangkan pengetahuan dan moral agama anak didik.

Oleh karena itu, peneliti melihat bahwa pengembangan pendidikan moral agama sangat penting di TK, untuk mendapatkan pengembangan terbaik dari segi kurikulum dalam bidang pendidikan moral agama pada tingkat pendidikan TK.

\section{Metode Penelitian}

Metode yang digunakan dalam penelitian ini yaitu metode $R \& D$. Metode R\&D yang dalam bahasa Inggrisnya research and development (penelitian dan pengembangan) adalah metode penelitian yang digunakan untuk menghasilkan produk tertentu dan atau menguji keefektifan produk tersebut (Sugiyono, 2016).

Adapun langkah-langkah penelitiannya yaitu: pertama, potensi dan masalah. Dalam konteks penelitian ini TK IT Salman alFarizi Kota Bandung dan TK IT alMultazam Kuningan merupakan lembaga pendidikan yang menyelenggarakan pembelajaran untuk anak usia dini. Namun dalam pelaksanaan kurikulumnya belum mengintegrasikan materi pendidikan moral agama. Kedua, mengumpulkan informasi. Ketiga, desain produk. Keempat, validasi desain. Kelima, perbaikan desain. Keenam, uji coba produk. Ketujuh, revisi produk.
Kedelapan, uji coba pemakaian. Kesembilan, revisi produk (Sugiyono, 2017).

Implementasi pengembangan dalam penelitian ini dilakukan melalui uji coba Rencana Pelaksanaan Pembelajaran (RPPH) yang telah peneliti susun, hal ini difokuskan dalam upaya meningkatkan kualitas proses pembelajaran moral agama pada anak usia dini. Upaya penerapan pembelajaran ini dilakukan melalui pengembangan kurikulum pendidikan moral agama dengan tiga tahapan, yaitu tahap persiapan, tahap pengembangan dan tahap pelaporan.

\section{Tahap Persiapan}

Data yang diperlukan dalam penelitian ini adalah data tentang pengembangan kurikulum pendidikan moral agama di TK IT Salman Al-Farisi Bandung dan TK IT Al-Multazam Kuningan tahun pelajaran 2016/2017 kelompok B sebanyak 150 anak didik.

Untuk memperjelas langkah-langkah khusus dan rinci dalam pelaksanaan pengumpulan data penelitian, penulis mendiskusikan hal ini dengan teman sejawat (pendidik TK IT Salman Al-Farisi Bandung dan TK IT Al-Multazam Kuningan) sebagai mitra. Dari hasil diskusi diperoleh kesepahaman mengenai hari dan tanggal pelaksanaan pembelajaran, tema pembelajaran, alokasi waktu pembelajaran, metode dan media pembelajaran, serta teknik evaluasi yang akan dipilih dalam menentukan keberhasilan proses pembelajaran moral dan agama.

Adapun pelaksanaan pengumpulan data untuk mengetahui pengembangan kurikulum pendidikan moral agama, dilakukan sebagai berikut: 1) pelaksanaan pembelajaran moral agama untuk mengembangkan kurikulum yang telah ada berupa RPPH dengan sub tema 'air karunia Allah Swt.', dengan topik 'manfaat air', dilaksanakan di TK IT Salman Al-Farisi Bandung dan TK IT Al-Multazam Kuningan mulai tanggal 07 Maret 2017 
sampai dengan selesai. 2). mengadakan pengamatan terhadap pendidik sebagai ahli materi dan anak didik TK dalam pelaksanaan pembelajaran moral agama dengan sub tema 'air karunia Allah Swt.', dengan topik 'manfaat air'. 3) mengolah data secara kualitatif yaitu menganalisis model dan mengevaluasi anak didik; sedangkan secara kuantitatif dengan menggunakan perhitungan statistik.

\section{Tahap Pengembangan}

Pada tahap pengembangan, dilakukan proses interaksi antara pendidik dan anak didik, anak didik dengan anak didik, serta anak didik dalam kelompok atau secara individual. Tahap pengembangan ini merupakan tahap pelaksanaan apa yang telah direncanakan oleh pendidik sehingga implementasinya dilaksanakan melalui proses uji coba selama 3 kali uji coba untuk memperoleh tujuan yang diinginkan sampai tercapainya ketuntasan belajar yang diharapkan (Sugiyono, 2018).

\section{Hasil Penelitian dan Pembahasan}

Berdasarkan pada tujuan penelitian, maka hasil penelitian ini mendeskripsikan tentang kurikulum pendidikan moral agama, implementasi kurikulum pendidikan moral agama, keunggulan pengembangan kurikulum moral agama, dan keefektifan kurikulum moral agama, maka hasil penelitian ini sebagai berikut:

Pertama, secara khusus untuk menjawab pengembangan kurikulum pendidikan moral agama yang ada di TK IT Salman Al-Farisi Bandung dan TK IT AlMultazam Kuningan yang sesuai dengan tujuan yang ingin dicapai dalam penyusunan $\mathrm{RPPH}$, maka tema disusun berdasarkan apa yang disarankan oleh guru kepada peneliti. Untuk itu dalam penelitian ini secara garis besar pengembangan kurikulum pendidikan moral agama tiap temanya mengandung nilai-nilai pembiasaan perilaku positif; penanaman kemandirian dan disiplin, serta pembinaan keimanan dan ketakwaan. Ketiga pengembangan tersebut selalu diterapkan kepada anak didik dalam setiap pembelajaran sebagai pendekatan utama pelaksanaan kegiatan pendidikan moral dan agama.

Dalam kehidupan sehari-hari di lingkungan satuan pendidikan TK IT Salman Al-Farisi Bandung dan TK IT AlMultazam Kuningan diterapkan ketiga tujuan tersebut dalam bentuk totalitas pendidikan dengan mengandalkan keteladanan, penciptaan lingkungan dan pembiasaan melalui berbagai tugas dan kegiatan. Oleh sebab itu, seluruh hal yang dilihat, didengar, dirasakan, dan dikerjakan oleh anak didik adalah pendidikan.

Kemandirian dan disiplin merupakan kepatuhan seseorang dalam mengikuti peraturan dan tata tertib yang berlaku dengan perilaku yang baik sehinggga pada akhirnya anak didik akan terbiasa melakukan perilaku yang baik itu. Kemandirian dan disiplin bukanlah suatu paksaan yang menyiksa anak didik, akan tetapi ini bermanfaat untuk masa depan bahkan berguna seumur hidupnya. Sebagaimana diungkapkan Morrison (2015) bahwa disiplin bukanlah tentang kepatuhan dan pengendalian, tetapi mencakup pembimbingan perilaku, sebuah proses dimana semua anak didik belajar mengendalikan dan mengarahkan perilaku mereka menjadi mandiri dan percaya diri.

Tujuan penanaman keimanan dan ketakwaan dimaksudkan untuk merangsang pembelajaran yang unggul terutama membina moral dan akhlak baik yang diharapkan dapat diwujudkan dalam kehidupan sehari-hari, yaitu perilaku yang memancarkan iman dan takwa kepada Allah Swt. dalam masyarakat, selain itu diharapkan dapat membantu anak didik mengembangkan berbagai potensi baik psikis dan fisik yang meliputi moral dan nilai-nilai agama, sosial emosional, kognitif, bahasa, fisik/ motorik, kemandirian dan seni untuk siap memasuki pendidikan dasar. 
Penanaman berupa pembentukan perilaku yang mulia dan bermoral tinggi yang dapat dilakukan melalui penanaman nilai-nilai yang berkaitan dengan keimanan, rasa kemanusiaan, hidup bermasyarakat dan bernegara, serta dapat meningkatkan keimanan dan ketakwaan kepada Allah Swt. serta membina sikap anak didik dalam rangka meletakkan dasar agama yang baik untuk diinternalisasikan dalam kehidupannya sehari-hari (Fahmi dkk., 2019).

Kedua TK IT tersebut telah berusaha menciptakan suasana yang kondusif bagi pertumbuhan positif anak didik di dalam kehidupan sehari-hari, sehingga anak didik merasakan nikmatnya kehidupan yang tenteram dan damai dengan penuh kasih sayang serta merasakan nikmatnya kehidupan beriman dan bertakwa yang akan membahagiakannya kelak. Karena, pembinaan keimanan dan ketakwaan akan menjadi pijakan akhlak seorang anak didik yang bersandar pada kondisi lingkungan yang ada di sekitarnya dan ia akan merasakan manfaat kehadiran-Nya.

Kedua, implementasi pengembangan kurikulum pendidikan moral agama pada penelitian ini adalah pengembangan pada perencanaan pembelajaran yakni pengembangan RPPH. Hasil pembelajaran membuktikan bahwa pengembangan kurikulum pendidikan moral agama di TK IT Salman Al-Farisi Bandung dan TK IT Al-Multazam Kuningan telah berhasil, hal ini berdasarkan hasil tindakan dan observasi tiap tahap yang dinilai, akan dibuat laporan data-datanya sebagai berikut:

Mempraktikkan cara memanfaatkan air dalam kehidupan sehari-hari

Kemampuan anak didik dalam mempraktikkan air dalam kehidupan sehari-hari pada anak didik kelompok B di TK IT Salman Al-Farisi Bandung dan TK IT Al-Multazam Kuningan setelah dilakukan tindakan pada tahap I diperoleh nilai rata-ratanya mencapai 2.53 . Ini artinya anak didik mulai berkembang dalam mempraktikkan air dalam kehidupan sehari-hari sehingga diperoleh persentase ketuntasan belajarnya sebesar $63.3 \%$ termasuk kategori sedang karena berada pada daerah interval antara $60-74 \%$. Pada tahap II diperoleh nilai rata-rata sebesar 2.89 dan persentase ketuntasan belajarnya mencapai 72.33 termasuk kategori sedang. Pada tahap III mengalami peningkatan dalam mempraktikkan air dalam kehidupan sehari-hari dengan nilai rata-rata sebesar 3.08 dan persentase ketuntasan belajarnya mencapai $77 \%$ termasuk kategori tinggi karena berada pada daerah interval antara 75 - 84\%. Hal ini telah berhasil mengembangkan pendidikan moral agama untuk aspek mempraktikkan air dalam kehidupan sehari-hari.

Menyebutkan cara memanfaatkan air sebagai karunia Allah

Menyebutkan cara memanfaatkan air sebagai karunia Allah Swt., mengandung nilai-nilai moral yang mengarah kepada pengembangan emosional, sosial, dan pengetahuan dalam kehidupan mereka sehari-hari yang dikembangkan di TK dalam program pembentukan perilaku. Jadi penting sekali dalam memahami cara memanfaatkan air sebagai gambaran bagi anak didik untuk memanfaatkan karunia Allah dengan sebaik-baiknya.

Menyebutkan cara memanfaatkan air sebagai karunia Allah Swt. yang dilakukan anak didik TK IT Salman Al-Farisi Bandung dan TK IT Al-Multazam Kuningan pada kelompok B diketahui pada tahap I anak didik belum memahami cara memanfaatkan air, sehingga diperoleh nilai rata-rata 2.52 dan persentase ketuntasan belajarnya $63.1 \%$ termasuk kategori sedang. Pada tahap II anak didik mulai berkembang sesuai harapan dalam menyebutkan cara memanfaatkan air dengan nilai rata-rata 3.03 dan persentase ketuntasan belajarnya $75.67 \%$ termasuk tinggi. Sedangkan tahap III anak didik berkembang sangat baik dengan nilai ratarata 3.14 dan persentase ketuntasan belajarnya $78.5 \%$ termasuk tinggi. 
Keberanian bertanya dengan kalimat sendiri tentang manfaat air sebagai karunia Allah

Keberanian anak didik untuk bertanya dengan kalimatnya sendiri dilakukan melalui tanya jawab. Keberanian untuk bertanya sebaiknya dilatih ketika masih usia dini. Hal ini dapat mendorong anak didik untuk lebih berani dan banyak bertanya dalam usaha mengetahui berbagai pengetahuan, khususnya tentang manfaat air sebagai karunia Allah Swt. dapat tergali dan berkembang.

Hal ini terbukti pada tahapan yang dilakukan, memperlihatkan bahwa pengembangan moral agama pada aspek keberanian anak didik untuk bertanya dengan kalimatnya sendiri tentang manfaat air sebagai karunia Allah, berkembang dengan baik. Pada tahap I diperoleh nilai rata-rata anak didik sebesar 2.48 dan persentase ketuntasan belajarnya $62 \%$ termasuk kategori sedang. Pada tahap II sudah mencapai kriteria yang ditetapkan dengan diperoleh nilai rata-rata sebesar 3.07 dan persentase ketuntasan belajarnya mencapai 76.67 termasuk kategori tinggi. Pada tahap III ini lebih meningkat lagi kriterianya dengan memiliki nilai rata-rata sebesar 3.08 dan nilai persentase ketuntasan belajarnya mencapai $77.16 \%$ termasuk kategori tinggi.

\section{Bermain peran cara memanfaatkan air dengan baik}

Pada saat tahap I aspek bermain peran cara memanfaatkan air dengan baik menunjukkan masih rendah dengan diperoleh nilai rata-rata sebesar 2.46 dan persentase ketuntasan belajarnya sebesar $61.5 \%$ termasuk kategori sedang. Pada siklus II mengalami peningkatan dengan nilai rata-rata sebesar 2.93 dan persentase ketuntasan belajarnya sebesar $73.33 \%$ termasuk kategori sedang. Pada tahap I dan II ini belum sesuai dengan kriteria yang ditetapkan, berarti pembelajaran pada kedua tahap tersebut belum memuaskan. Selanjutnya pada tahap III diperoleh nilai rata-rata sebesar 3.19 dan persentase ketuntasan belajarnya meningkat dengan nilai sebesar $79.83 \%$ sudah sesuai dengan kriteria yang ditetapkan sehingga nilai ini termasuk kategori tinggi.

Anak didik mau berbagi minuman dan alat main dengan semua teman dalam memanfaatkan air

Selain setelah dibekali pengetahuan berupa teori keagamaan, juga memperoleh bekal yang sangat penting untuk mengamalkan kebaikan dalam kehidupan sehari-hari, misalnya anak didik mau berbagi minuman dan alat main dengan semua teman dalam memanfaatkan air sebagai karunia Allah Swt.

Pada aspek ini menunjukkan bahwa berbagi dengan teman merupakan pijakan bagi anak didik untuk selalu melakukan kebaikan. Hal ini didukung dengan hasil dari pembelajaran tahap I yang memperoleh nilai rata-ratanya sebesar 2.4 dan persentase ketuntasan belajarnya sekitar $60 \%$ termasuk kategori sedang. Pada tahap II diperoleh nilai rata-rata sebesar 2.86 dengan persentase ketuntasan belajarnya mencapai $71.5 \%$ termasuk kategori sedang. Pada kedua tahap tersebut belum mencapai kriteria yang ditetapkan, akan tetapi pada tahap selanjutnya sudah mencapai kriteria yang ditetapkan, ini terbukti dengan meningkatnya nilai rata-rata sebesar 3.02 dengan persentase ketuntasan belajarnya sebesar $75.67 \%$ termasuk kategori tinggi. Walaupun pada aspek penilaian ini yang paling rendah dibandingkan dengan aspek lainnya, tetapi pembelajarannya telah berhasil sesuai dengan kriteria penilaian.

Dengan demikian, pengembangan kurikulum pendidikan moral agama pada tiap aspek penilaiannya meningkat dan berkembang lebih baik, ini semua berkat usaha pendidik dalam meningkatkan kemampuan mengajarnya. Tingkat kinerja pendidik dalam mengembangkan pendidikan moral agama di TK IT Salman Al-Farisi Bandung dan TK IT Al-Multazam Kuningan berdasarkan hasil observasi yang dibantu observer pada masing-masing tahap bahwa proses pembelajaran yang 
dilaksanakan pendidik pada tahap I termasuk baik dari segi persiapan pendidik diperoleh 50\%, pelaksanaan kinerja pembelajaran pun termasuk baik dengan nilai 58.33\%; dan pada kinerja evaluasi baik sekali diperoleh $100 \%$. Peningkatan kinerja pendidik meningkat pada tahap II, dari segi persiapan termasuk baik sekali dengan nilai $75 \%$; pelaksanaan pembelajaran termasuk baik dengan nilai $66.67 \%$; dan pelaksanaan evaluasi termasuk baik sekali dengan nilai $100 \%$.

Peningkatan kinerja pendidik semakin meningkat pada tahap III dengan nilai sangat baik jika dilihat dari segi persiapan $100 \%$, sedangkan pada segi pelaksanaan pembelajaran termasuk baik dengan persentase $75 \%$, dan kinerja evaluasi pendidik sangat baik dengan nilai $100 \%$. Hasil peningkatan kinerja pendidik tersebut dapat digambarkan dalam grafik pada gambar 1. Observasi terhadap aktivitas anak didik dan pendidik pada setiap tahap uji coba pengembangan pendidikan moral agama telah terlaksana dengan baik. Berdasarkan pelaporan yang peneliti susun di atas, maka pembuatan pelaporan untuk mengetahui kelayakan produk setelah dilakukan penguji produk selama 3 tahap.

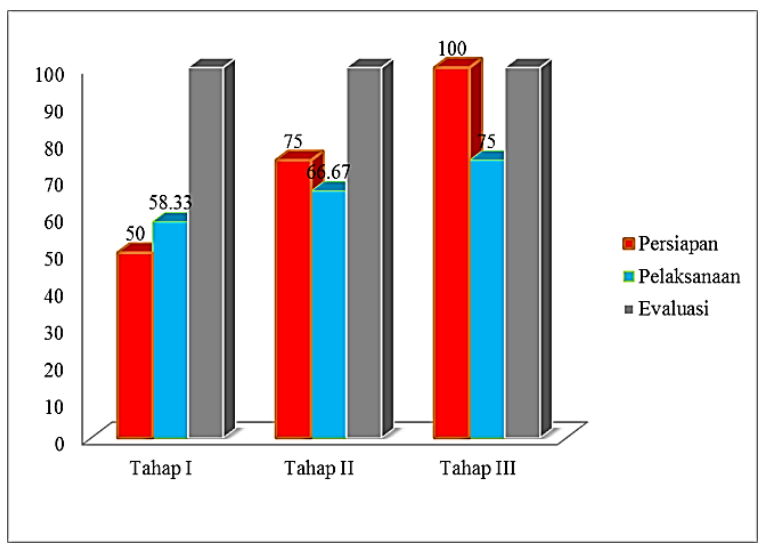

Gambar 1. Peningkatan kinerja pendidik pada tiap tahap
Tujuan pembuatan pelaporan ini dimaksudkan untuk menentukan produk pengembangan kurikulum pendidikan moral agama yang peneliti susun berupa RPPH siap digunakan di TK yang peneliti lakukan juga di TK lainnya.

Keunggulan pengembangan kurikulum pendidikan moral agama di TK IT Salman Al-Farisi Bandung dan TK IT Al-Multazam Kuningan.

Keunggulan sekolah IT adalah adanya pelajaran agama Islam yang lebih intensif. Di TK IT ini pelajaran agamanya lebih banyak yang terkait dengan agama misalnya mengaji, sholat, wudhu, belajar bahasa Arab, hafalan doa dan lain sebagainya. Adanya kurikulum yang luwes dalam pendidikan moral agama yang berorientasi pada pencapaian pemahaman anak didik.

Pelatihan budi pekerti menurut tuntunan agama Islam. Sejak masuk ke gerbang sekolah sampai pulang sekolah, anak didik dilatih untuk berlaku sesuai dengan tuntunan agama Islam. Misalnya datang ke sekolah disambut pendidik, menyalami dengan mencium tangan sambil mengucapkan salam, sebelum belajar berdoa begitupun dengan sesudahnya sampai pelajaran berakhir diikuti dengan pembiasaan yang baik.

Banyak kegiatan tambahan yang positif seperti kegiatan memperingati hari besar Islam, pendidikan moral dan agama telah diintegrasikan dengan aspek yang lainnya, pendidik yang profesional sehingga dapat meningkatkan keberhasilan pembelajaran dan meningkatkan kompetensi pendidik terutama pada kompetensi pribadi pendidik. Adanya kompetensi yang sesuai dengan tuntutan fungsi dan tujuan pendidikan nasional, di samping itu terdapat kompetensi yang sifatnya berkembang pada perilaku dan pendidikan karakter. Adanya penilaian yang menyeluruh dari semua aspek penilaian, sehingga penentuan nilai bagi anak didik di TK bukan dinilai tes saja, tetapi juga diperoleh dari nilai 
kesopanan, religi, praktek, sikap dan lainlain.

Pembelajaran yang berpusat pada anak didik dengan penggunaan metode yang lebih bervariasi, adanya kerjasama dengan orang tua yang banyak melibatkan orang tua dalam kegiatan keagamaan, dan peralatan lengkap, banyaknya alat bermain, juga gedung sudah memenuhi syarat untuk melaksanakan kegiatan belajar.

\section{Tingkat keefektifan pengembangan kurikulum pendidikan moral agama di TK IT Salman Al-Farisi Bandung dan TK IT Al-Multazam Kuningan.}

Berdasarkan hasil wawancara dengan Kepala TK IT Salman Al-Farisi Bandung dan TK IT Al-Multazam Kuningan dapat dibahas bahwa hal-hal yang bisa dijadikan penentu keberhasilan pendidikan moral dan agama tidak lepas dari unsur potensi atau kemampuan anak didik, pendidik profesional, fasilitas sekolah dan sentuhansentuhan manajemen. Pada aspek penyelenggaraan pendidikan dengan pendidikan yang inovatif dan berorientasi pada peningkatan kualitas anak didik.

Untuk mengetahui efektivitas pengembangan kurikulum pendidikan moral agama di Taman Kanak-Kanak tersebut bisa dilihat dari 3 proses pengembangannya yaitu proses pembelajaran, proses aktivitas belajar anak didik dan proses evaluasi yang ingin dicapai (Leksono dkk., 2018). Upaya menciptakan proses pembelajaran efektif, dapat dilakukan dengan mewujudkan perilaku mengajar yang efektif pada pendidik, dan mewujudkan perilaku belajar yang terkait dengan proses pembelajaran (Syafei, 2015). Pendapat tersebut diperkuat lagi oleh Nurdin (2016) yang menyebutkan bahwa supaya pembelajaran efektif terdapat 3 karakteristik yang harus dikembangkan yaitu kegiatan belajar mengajar, aktivitas belajar dan prestasi belajar anak didik.

Dengan demikian dapat dipahami bahwa efektivitas pengembangan kurikulum pendidikan moral agama bisa diketahui dari pembentukan tujuan pembelajaran, berlangsungnya proses pembelajaran yang aktif, efektif dan menyenangkan, materi yang disampaikan, dan evaluasi (Azis, 2018). Keadaan aktif dan menyenangkan tidaklah cukup jika proses pembelajaran tidak efektif, yaitu tidak menghasilkan apa-apa yang harus dikuasai anak didik setelah proses pembelajaran berlangsung, sebab pembelajaran memiliki sejumlah tujuan pembelajaran yang harus dicapai. Karena itu untuk mengetahui efektivitas pengembangan kurikulum pendidikan moral agama dapat diketahui dari tujuan yang hendak dicapai, pembelajaran berupa informasi yang disajikan dapat diserap oleh anak didik secara optimal, sehingga menimbulkan perubahan tingkah laku pada diri anak didik yaitu tercapainya tujuan pembelajaran.

Jadi dalam penelitian ini pengembangan kurikulum pendidikan moral agama telah dilaksanakan seefektif mungkin dengan melaksanakan penyusun-an tujuan pembelajaran, proses pembelajaran agar anak didik dapat mengikuti pembelajaran dengan sungguh-sungguh, sehingga proses pembelajaran tersebut dapat menghasilkan sesuatu informasi berupa pengetahuan, sikap dan keterampilan yang berguna bagi anak didik di masa depannya. Karena bila kita rajin melatih anak didik dalam hal keagamaan melalui kegiatan berdoa, beribadah menurut agamanya masingmasing, serta berperilaku sesuai ajaran agama, diyakini anak didik akan menjadi orang yang agamis, taat beribadah dan memiliki kepedulian tinggi terhadap aktivitas keagamaan (Mansur, 2016).

Berdasarkan hasil uji coba secara bertahap di atas dengan tujuan untuk mengumpulkan informasi yang dapat digunakan untuk memperbaiki pembelajaran, masukan (feedback) dari koordinator dan pengajar yang melaksanakan pembelajaran dikumpulkan dan didiskusikan bersama-sama sehingga bisa diambil kesimpulan. 


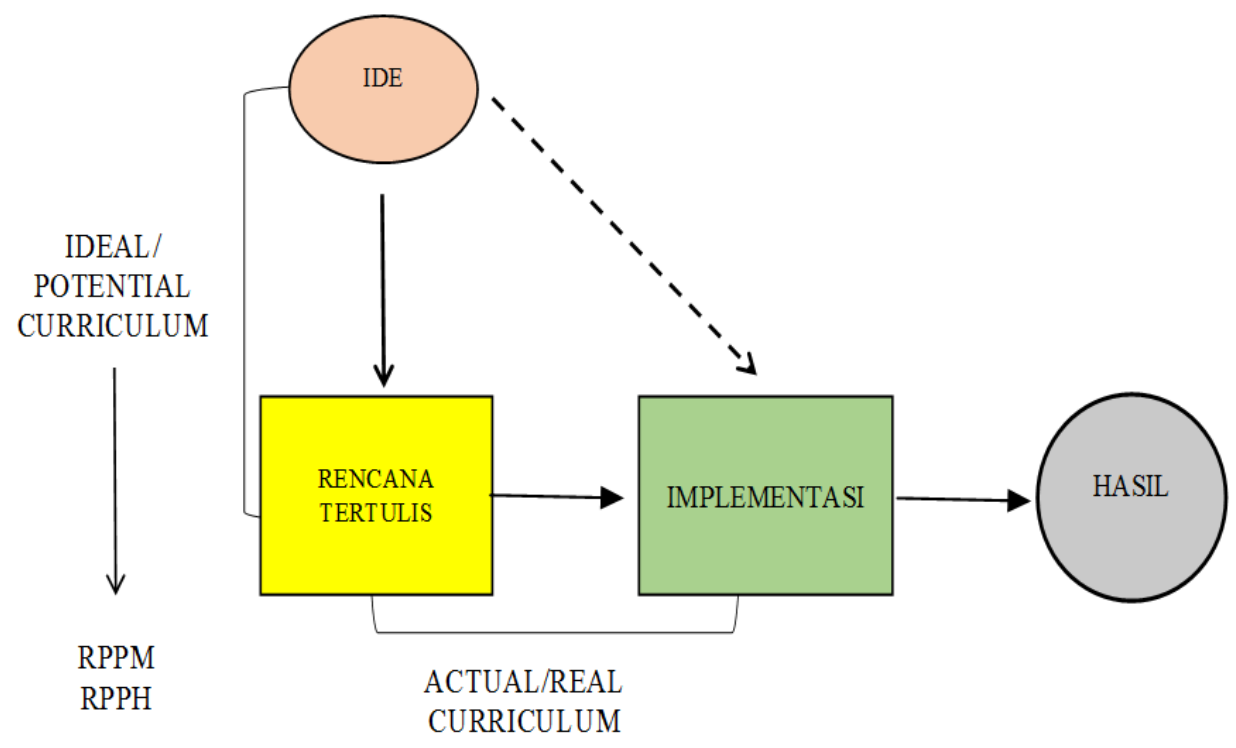

Gambar 2. Alur pemetaan konsep pengembangan kurikulum moral agama di TK dalam penyusunan RPPH di TK Islam

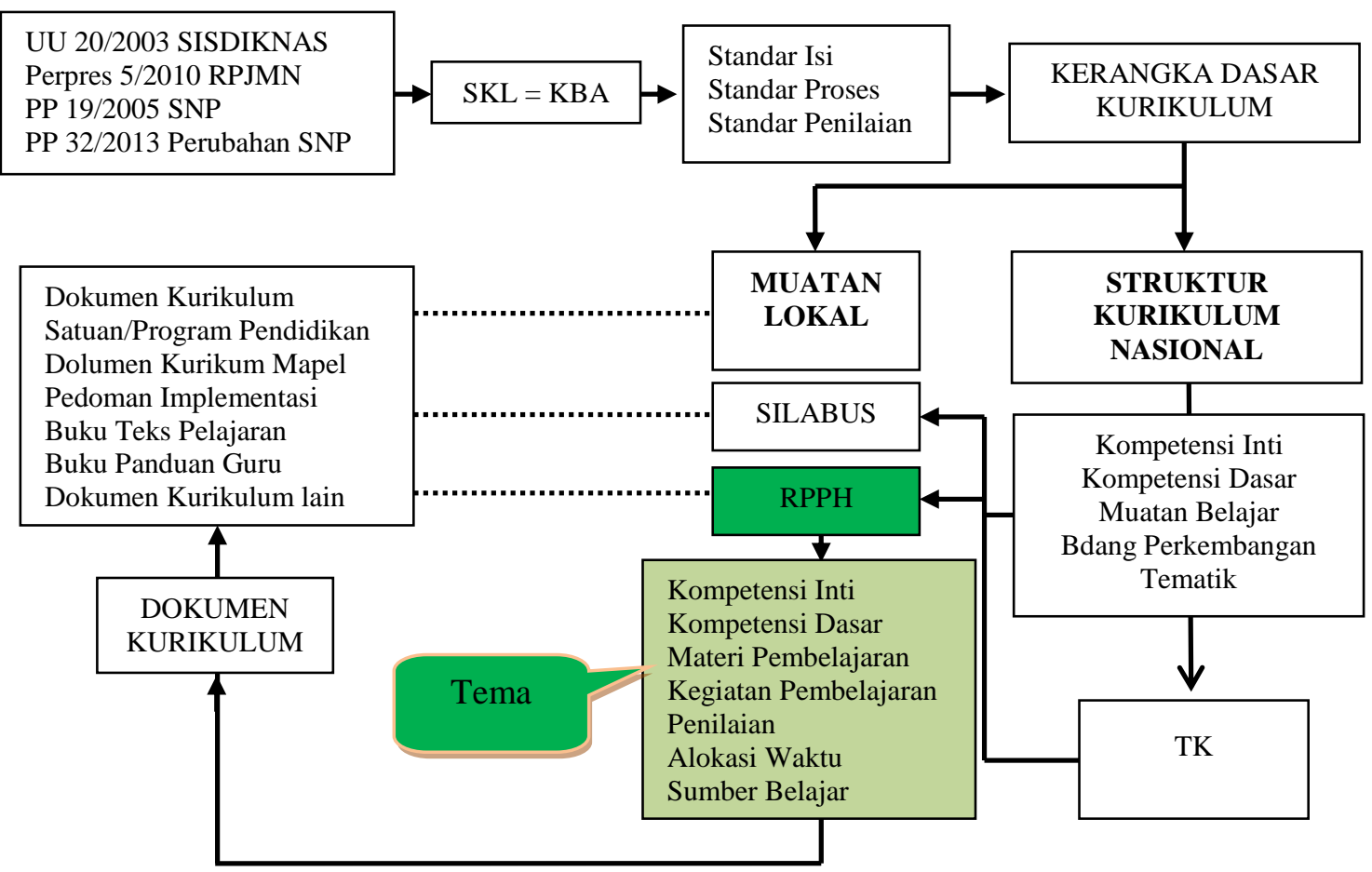

Gambar 3. Alur pengembangan kurikulum pendidikan moral agama di TK Islam 


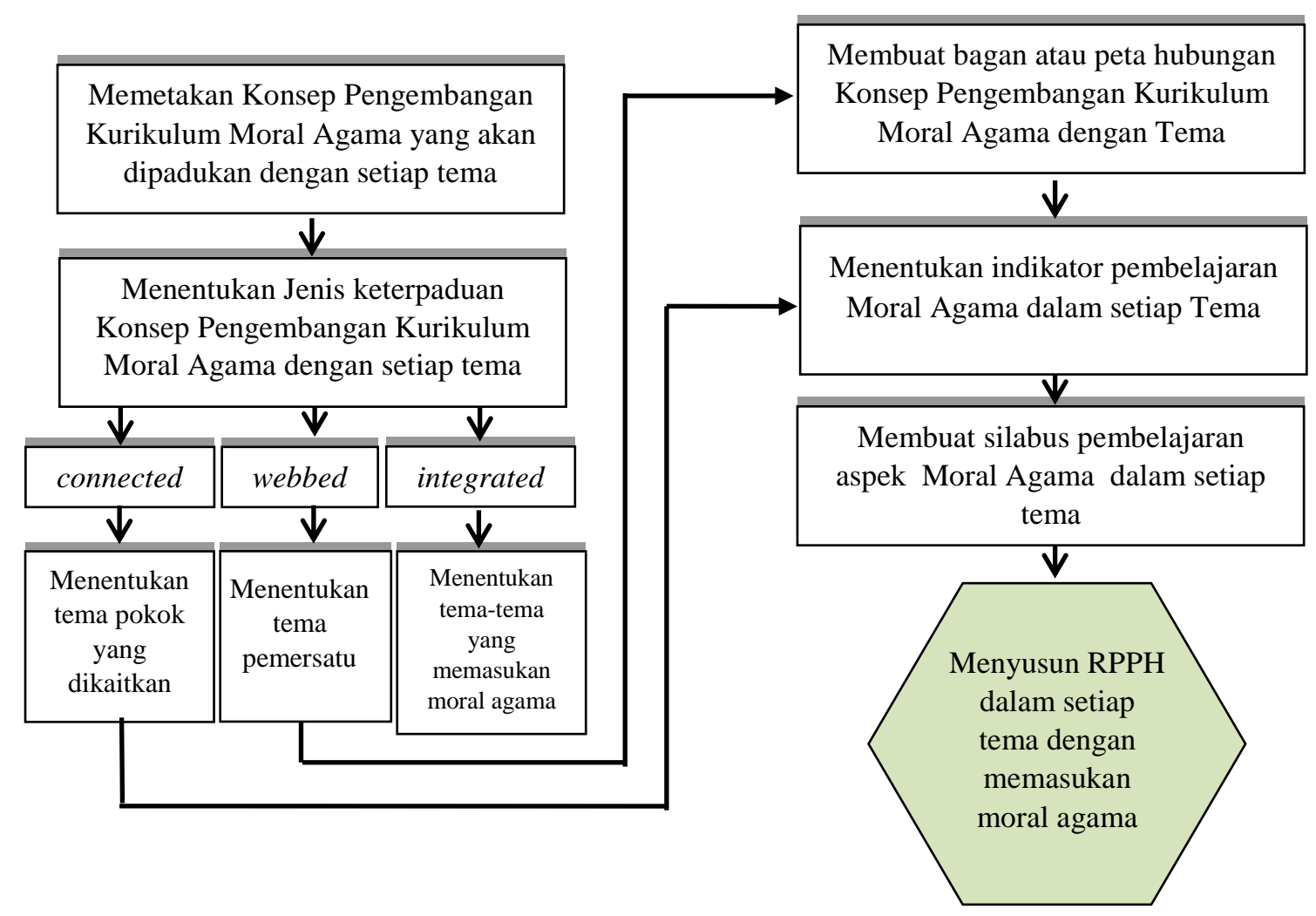

Gambar 4. Alur pemetaan konsep pengembangan kurikulum moral agama di TK dalam penyusunan RPPH di TK Islam

Wawancara dipusatkan pada bagianbagian pembelajaran atau materi yang perlu mendapat perhatian sehingga operasional pembelajaran menjadi lebih efektif. Efektivitas pengembangan bisa dinilai dari proses pembelajaran yang berlangsung secara terus-menerus untuk mencapai tujuan yang diinginkan.

\section{Penawaran Gagasan}

Berdasarkan hasil analisis temuan di lokasi penelitian, yaitu di TK IT Salman Al-Farisi Bandung dan TK IT Al-Multazam Kuningan, peneliti menawarkan gagasan untuk melaksanakan pengembangan kurikulum pendidikan moral agama di Taman Kanak-kanak diantaranya model pengembangan pada gambar 2, alur pengembangan kurikulum pada gambar 3 , dan alur pemetaan konsep pengembangan pada gambar 4.

\section{Model Pengembangan Kurikulum Pendidikan Moral Agama di TK Islam}

Berdasarkan pada model pengembangan kurikulum moral agama di TK, peneliti mengembangkannya dalam beberapa tahap yaitu model pengembangan kurikulum moral agama (gambar 2), alur pengembangan kurikulum (gambar 3), dan alur pemetaan konsep pengembangan (gambar 4).

\section{Simpulan}

Kurikulum pendidikan moral agama yang dikembangkan di TK IT Salman AlFarisi Bandung dan TK IT Al-Multazam Kuningan difokuskan pada pembiasaan perilaku positif, penanaman kemandirian dan disiplin, dan pembinaan keimanan dan ketakwaan. Ketiga pengembangan ini diterapkan dari sejak anak datang ke sekolah sampai pulang sekolah melalui kegiatan rutin secara terus-menerus setiap hari. 
Implementasi pengembangan kurikulum pendidikan moral agama di TK IT Salman Al-Farisi Bandung dan TK IT AlMultazam Kuningan dilakukan dengan tiga tahap yaitu tahap persiapan dengan menentukan tujuan pembelajaran, menyiapkan RPPH, menyiapkan lembar penilaian dan lembar observasi kinerja pendidik.

Pengembangan kurikulum pendidikan moral agama di TK IT Salman Al-Farisi Bandung dan TK IT Al-Multazam Kuningan memiliki keunggulan yaitu: pelajaran agama Islam di kedua sekolah tersebut lebih intensif, adanya kurikulum yang mengarah pada pendidikan karakter dan pengembangan diri, banyaknya kegiatan keagamaan, pendidik yang profesional, materi pendidikan moral dan agama yang diintegrasikan dengan aspek lainnya, sarana dan prasarana yang lengkap dan tersusun rapi.

\section{Daftar Pustaka}

Annisa, Y. N. (2016). Home-start parenting program untuk meningkatkan fungsi emosi ibu dalam pengasuhan anak usia dini. Psympathic: Jurnal Ilmiah Psikologi, 3(1), 1-22. https://doi.org/10.15575/psy.v3i1.1096

Azis, R. (2018). Implementasi pengembangan kurikulum. Inspiratif Pendidikan. $\quad 7(1), \quad 44-50$. https://doi.org/10.24252/ip.v7i1.4932

Cahyaningrum, E. S., Sudaryanti, S., \& Purwanto, N. A. (2017). Pengembangan nilai-nilai karakter anak usia dini melalui pembiasaan dan keteladanan. Jurnal Pendidikan Anak, $6(2)$, 203-213. https://doi.org/10.21831/jpa.v6i2.1770 7

Danoebroto, S. W. (2015). Teori belajar konstruktivis Piaget dan Vygotsky. Indonesian Digital Journal of Mathematics and Education, 2(3), 191198.

Fadlyana, E., \& Larasaty, S. (2016).
Pernikahan usia dini dan permasalahannya. Sari Pediatri, 11(2), 136-141.

https://doi.org/10.14238/sp11.2.2009.1 36-41

Fahmi, I., Takwin, B., \& Muhamad, R. (2019). Nilai moral sebagai prediktor orientasi politik pada anggota organisasi keagamaan. Psympathic: Jurnal Ilmiah Psikologi, 6(2), 165180.

https://doi.org/10.15575/psy.v6i2.6260

Holis, A. (2016). Belajar melalui bermain untuk pengembangan kreativitas dan kognitif anak usia dini. Jurnal Pendidikan Universitas Garut 10(1), 23-37.

Hurlock, E. (2014). Perkembangan anak edisi keenam Jilid I. Penerbit Erlangga.

Inawati, A. (2017). Strategi pengembangan moral dan nilai agama untuk anak usia dini. Jurnal Pendidikan Anak, 3(1), 5164.

Irma, C. N., Nisa, K., \& Sururiyah, S. K. (2019). Keterlibatan orang tua dalam pendidikan anak usia dini di TK Masyithoh 1 Purworejo. Jurnal Obsesi : Jurnal Pendidikan Anak Usia Dini, 3(1), 214-224. https://doi.org/10.31004/obsesi.v3i1.15 2

Jannah, M. (2015). Tugas-tugas perkembangan pada usia kanak-kanak. Gender Equality: International Journal of Child and Gender Studies, 408(19), 4076-4084. https://doi.org/10.1016/j.scitotenv.2010 .05 .022

Khaironi, M. (2018). Perkembangan anak usia dini. Jurnal Golden Age, 2(1), 112.

Leksono, F. D., Sulton, S., \& Susilaningsih, S. (2018). Implementasi kurikulum 2013 di TK TPI Nurul Huda Malang Kelompok A1. JINOTEP (Jurnal Inovasi dan Teknologi Pembelajaran) Kajian dan Riset dalam Teknologi Pembelajaran, 4(2), 126-131.

Mansur, R. (2016). Pengembangan 
kurikulum pendidikan agama Islam multikultural (Suatu prinsip-prinsip pengembangan). Vicratina: Jurnal Kependidikan Dan Keislaman, 1(2).

Morrison, George. (2015). Educación infantil - George S. Morrison - Google Libros.

Nurdin, S. (2016). Pengembangan kurikulum, silabus dan satuan acara perkuliahan (sap) di perguruan tinggi agama islam. Ta'dib, 16(1), 18-27. https://doi.org/10.31958/jt.v16i1.234

Prakoso, B. H., Ramdani, Z., \& Rahmah, B. (2020). Best pratices of character education in leading schools in Bandung. Indonesian Journal of Educational Assessment, 3(1), 61-71. https://doi.org/10.26499/ijea.v3i1.61

Rustini, T. (2018). Pendidikan karakter anak usia dini. Cakrawala Dini: Jurnal Pendidikan Anak Usia Dini. 3(1). https://doi.org/10.17509/cd.v3i1.10321

Sugiyono, P. D. (2017). Metode penelitian kuantitatif kualitatif dan $R \& D$. Alfabeta.

Sugiyono, P. D. (2016). Metode penelitian kuantitatif, kualitatif, dan $R \& D$, Alfabeta.

Suryana, D. (2016). Pendidikan anak usia dini: Stimulasi dan aspek perkembangan anak. Kencana.

Wahyuningsih, D., \& Suyanto, S. (2015). Implementasi kearifan lokal melalui model BCCT untuk pengembangan kemampuan sosial anak usia dini. JPPM (Jurnal Pendidikan dan Pemberdayaan Masyarakat), 2(1), 1023.
Syafei, I. (2016). Pengembangan model pembelajaran untuk meningkatkan kemampuan berpikir kritis siswa. Psympathic: Jurnal Ilmiah Psikologi, 2(2), 133-140. https://doi.org/10.15575/psy.v2i2.454

Tafsir, A. (2007). Ilmu pendidikan dalam perspektif islam. PT Remaja Rosdakarya.

Taubah, M. (2016). Pendidikan anak dalam keluarga perspektif islam Mufatihatut Taubah (Dosen STAIN Kudus Prodi PAI). Jurnal Pendidikan Agama Islam. 3(1), 109-136.

Wulandari, R., Ichsan, B., \& Romadhon, Y. A. (2017). Perbedaan perkembangan sosial anak usia 3-6 tahun dengan pendidikan usia dini dan tanpa pendidikan usia dini di kecamatan peterongan jombang. Biomedika, 8(1), 47-53.

https://doi.org/10.23917/biomedika.v8i 1.2900 
Psympathic, Jurnal Ilmiah Psikologi Juni 2020, Vol. 7, No. 1, Hal. : 141-154 